\title{
ESTIMATION OF HYPERTENSION RISK FROM LIFESTYLE FACTORS IN COASTAL POPULATIONS
}

\author{
Zata Ismah $^{\mathrm{a}^{*}}$; Tri Bayu Purnama ${ }^{\mathrm{b}}$; Reinpal Falefic ${ }^{\text {; }}$ Luthfiah Mawar $^{\mathrm{d}}$; Cindy Lestarie ; \\ Citra Cahyati Nst ${ }^{f}$
}

\author{
a,b,c,d,e,f Public Health Faculty ; Universitas Islam Negeri Sumatera Utara ; IAIN No. 1 ; \\ Medan 20371 ; Indonesia
}

\begin{abstract}
The prevalence of hypertension in coastal areas was still high between 2007 and 2018 with the highest prevalence in 2007 at $53.3 \%$. The purpose of this research was to analyze the prediction of hypertension based on the determinants of the lifestyle of the coastal population. The type of this research is using cross-sectional research design, with a total sample of 210 people in the coastal area of Medan Belawan. The data were collected using an instrument in the form of a questionnaire, body mass index measurement using a manual weight balance and a stature meter and blood pressure using an sphygmomanometer aneroid. The selection of candidates as predictive variables is carried out by chi-square test analysis, followed by multivariate analysis using binary logistic regression test and the formulation model to find predictions hypertension, namely age $\geq 45$ years has a 3.040 times greater risk of suffering from hypertension than age $<45$ years $(p=0.001 ; 95 \% C I=1.549-5.966)$ and obesity nutritional status has a large 2.284 times greater risk of suffering from hypertension than nutritional status was not obese $(\mathrm{p}=0.028 ; 95 \% \mathrm{CI}=$ 1.091-4.780). The results of the calculation of the probability from the modeling, it is found that if a person is $\geq 45$ years old and has a nutritional status of obesity, the probability of suffering hypertension is $99.99 \%$.
\end{abstract}

Keywords: Hypertension; Lifestyle; Modeling; Coastal

\section{Introduction}

Indonesia has a large coastal area and has the most islands in the world and $60 \%$ of Indonesia's population lives in coastal areas (BPS, 2016). The prevalence of hypertension in coastal areas is quite high, such as in China at 21.5\% (Chen et al., 2014), India at 46.6\% (Muthukrishnan, Pillai Uma, \& V., 2018), Brazil at $44 \%$ (Begossi, 2013). A literature study that the prevalence of hypertension specifically in coastal areas ranged from $6.45 \%$ to $51.1 \%$ (Yodang \& Nuridah, 2019). This is not much different from coastal areas in Indonesia, based on Riskesdas data from 2007 to 2018 based on coastal areas, so coastal areas still have a high prevalence of hypertension. The highest prevalence of hypertension was in 2007 at $53.3 \%$ in the coastal areas of the Natuna Islands (Indonesian Health Ministry, 2007, 2013, 2018).

\footnotetext{
*) Corresponding Author (Zata Ismah)

E-mail: zataismah@uinsu.ac.id
}

The problem of non-communicable hypertension is still a national priority. This is evidenced by the 2018 Riskesdas data with a prevalence of $34.1 \%$, which increased from 2013. The results of previous research showed that hypertension was more prevalent in coastal areas compared to non-coastal areas due to lifestyle and the tendency to like to consume high amounts of salt (Ingrid, S. K. Krishnadath1, Vincent W. V. Jaddoe, 2016; Rahajeng, Ekowati, Dewi Kristanti, 2016). Previous studies have also shown that hypertension is more common in coastal areas than in mountainous areas (Rusliafa, Amiruddin, \& Noor, 2014). Many of the coastal populations have low income levels and women in coastal areas work as housewives, so they have a passive lifestyle meaning that they do less physical activity because they are only housewives where household work is unstructured and usually not repetitive so it is less health benefits are not the same as structured 
exercise such as running (Julkrismi, 2018). This is supported by Dina's research (2014), where populations of coastal areas have a passive lifestyle caused by the low level of economy and education of coastal populations.

In epidemiology, there are several statistical analyzes in determining the causality of disease. Bivariate analysis is the most widely used analysis to see the relationship or influence between variables $x$ to $Y$. However, this analysis is unable to see the interaction between variables and is less able to control confounding and is less able to show which variables have the most influence. Modeling in epidemiological analysis aims to find predictor variables that are relevant to forecasting the incidence of cases. Modeling also aims to predict and foretells the probability of disease occurrence from a combination of several influencing variables, so that effective and efficient intervention actions can be planned.

Although coastal residents have a passive lifestyle, this research and other similar researches have not been able to predict the incidence of hypertension in coastal areas, so it is not clear what the biggest risk factor is for coastal populations and how far it causes hypertension to these risk factors. Therefore, it is necessary to model the prediction of the incidence of hypertension based on the determinants of the lifestyle of the coastal population.

\section{Method}

\section{Types of Research}

The type of this research is observational analytic using a cross-sectional research design. The use of this design is used to determine the true magnitude of the problem of hypertension in coastal areas in the population, then the exposure and effects will be studied at the same time.

\section{Location and Time of Research}

This research was conducted in the coastal area of Medan Belawan District, Medan City, North Sumatra Province. All selected samples are scattered throughout the sub-district. This research was conducted from April to September 2019.

\section{Population and Research Sample}

The population in this study are population of the coastal area of Medan Belawan. Samples are people in the coastal area of Medan Belawan who have been selected and meet the inclusion and exclusion criteria. The sample size obtained was 210 people. The inclusion criteria in this study are: 1 . Permanent residents of the Medan Belawan area with an age of $>18$ years; 2 . The woman is not pregnant. 2. People diagnosed with hypertension and not suffering from hypertension based on blood pressure measurements in this study were also included. The exclusion criteria were: 1 . Consuming food that does not come from one's own (family) cooking on a regular basis; 2 . Have a history of adrenal disorder; 3 . Consume hypertension drugs because to avoid bias in the blood pressure variable because they have received antihypertensives and their blood pressure is controlled considering that the sampling method in this study used random sampling so that respondents who did not have hypertension were also included in this study.

\section{Instrument}

To obtain hypertension status data, blood pressure screening was performed using an sphygmomanometer aneroid with the help of a nurse. To obtain data on salt and vegetable consumption patterns, interviews were conducted (asked directly by researchers) using a qualitative Food Frequency Questionnaire (FFQ). To obtain data on the nutritional status of respondents, the body mass index was measured using a manual weight balance and a stature meter. Then the other variables were collected by interview using a questionnaire.

\section{Data analysis}

Data analysis that will be carried out is univariate, bivariate to multivariate data analysis. The univariate analysis in this study aims to see the frequency distribution and central distribution. Bivariate analysis using this type of statistical test used the chi-square test with error on an alpha of $5 \%$. Multivariate statistical analysis was used to create a regression model for the incidence of hypertension using binary logistic statistical tests.

\section{Result and Discussion}

Based on table 1, it is found that the prevalence of hypertension in the coastal population of Medan Belawan is still high (31\%). Thus, from 10 coastal residents, there are 3 to 4 people who suffer from hypertension. Based on table 2, it is obtained that the average blood pressure in all samples in the coastal area of Medan Belawan is in the pre-hypertension category. However, the average blood pressure in 
patients with hypertension is included in the category of level 2 hypertension.

Table 1. Prevalence of Hypertension in the Coastal Population of Medan Belawan $(n=210)$

\begin{tabular}{lccc}
\hline \multicolumn{1}{c}{ Variable } & Frequency & Percentage & 95\% CI \\
\hline Hypertension & 65 & 31 & $23.5-38.3$ \\
Not Hypertension & 145 & 69 & $61.7-76.5$
\end{tabular}

Table 2. Systolic and Diastolic Blood Pressure in the Coastal Population of Medan Belawan

\begin{tabular}{lccccc}
\hline \multicolumn{1}{c}{ Blood Pressure } & Mean & SD & Min Max & 95\% CI \\
\hline Sample $(\mathrm{n}=210)$ & & & & & \\
Systolic $(\mathrm{mmHg})$ & 133.32 & 30.265 & 90 & 266 & $129.20-137.44$ \\
Diastolic $(\mathrm{mmHg})$ & 80.55 & 9.425 & 60 & 150 & $79.29-81.81$ \\
Hypertension $(\mathrm{n}=65)$ & & & & \\
Systolic (mmHg) & 170.43 & 29.018 & 140 & 266 & $163.24-177.62$ \\
Diastolic $(\mathrm{mmHg})$ & 86.39 & 12.412 & 80 & 150 & $83.31-89.47$ \\
\hline
\end{tabular}

Based on table 3, the characteristics of respondents with hypertension have a high level of salt consumption, the majority have obesity nutritional status, do not have routine exercise habits, the majority have low work status, low vegetable consumption, the population is more at risk of hypertension. Based on table 4, the results of multivariate analysis using logistic regression, it is known that the most dominant risk factors for the incidence of hypertension are age with an OR of $3.040(p=0.001 ; 95 \% C I=1.549-5.966)$ and obesity nutritional status with an OR of 2.284. (p $=0.028 ; 95 \% \mathrm{CI}=1.091-4.780)$. Based on table 5 , the probability of the incidence of hypertension in the coastal area of Medan Belawan will be smaller if a person does not have one or all of the risk factors above.

Based on the multivariate analysis that was carried out using binary logistic regression, it was found that the age variable was the dominant variable for the occurrence of hypertension in the coastal areas of Medan Belawan. Age $\geq 45$ years had a 3.040 times greater risk of suffering from hypertension than those aged $<45$ years $(\mathrm{p}=$ 0.001 ). This is in line with the results of research conducted by Widjaya (2018), Tamamilang (2018), and Adam (2019) namely that there was a relationship between age and the incidence of hypertension with a consecutive $\mathrm{p}$ value of $\mathrm{p}$ $<0.000 ; p=0.003$; and $p=0.003$. Based on Aidha's research (2019), age is one of the factors that are a risk or cause of hypertension that cannot be changed. Increasing age will cause a decrease in the body's functional system, one of which is a decrease in the elasticity of blood vessels and the work of the heart. The age at risk for hypertension is $\geq 45$ years. This is because at the age of $\geq 45$ years, the artery walls will experience thickening as a result of collagen buildup in the muscle layer and cause narrowing and stiffness (Kozier, 2010).

Table 3. Analysis of Population Characteristics with Hypertension Status

\begin{tabular}{|c|c|c|c|c|c|c|}
\hline \multirow{3}{*}{ Variable } & \multicolumn{4}{|c|}{ Hypertension Status } & \multirow{3}{*}{ OR } & \multirow{3}{*}{ Sig } \\
\hline & \multicolumn{2}{|c|}{ Hypertension } & \multicolumn{2}{|c|}{ Normal } & & \\
\hline & $\mathrm{n}$ & $\%$ & $\mathrm{n}$ & $\%$ & & \\
\hline \multicolumn{7}{|l|}{ Salt Consumption } \\
\hline $\begin{array}{l}\text { High } \\
(\geq 0.4 \text { Teaspoon) }\end{array}$ & 61 & 32.1 & 129 & 67.9 & $\begin{array}{c}1.891 \\
(0.607-5.898)\end{array}$ & 0.390 \\
\hline \multicolumn{6}{|l|}{ (<0.4 Teaspoon) } & \\
\hline \multicolumn{7}{|l|}{ Nutritional Status } \\
\hline $\begin{array}{l}\text { Obesity } \\
(>27 \mathrm{~kg} / \mathrm{m} 2)\end{array}$ & 34 & 42 & 47 & 58 & $\begin{array}{c}2.532 \\
(1.303-4.921)\end{array}$ & 0.038 \\
\hline $\begin{array}{l}\text { Overweight } \\
(25.1-27 \mathrm{~kg} / \mathrm{m} 2)\end{array}$ & 8 & 32 & 17 & 68 & $\begin{array}{c}1.647 \\
(0.620-4.372)\end{array}$ & \\
\hline $\begin{array}{l}\text { Normal } \\
(18.5-25 \mathrm{~kg} / \mathrm{m} 2)\end{array}$ & 20 & 22.2 & 70 & 77.8 & References & \\
\hline $\begin{array}{l}\text { Thin } \\
(<18.5 \mathrm{~kg} / \mathrm{m} 2)\end{array}$ & 3 & 21.4 & 11 & 78.6 & $\begin{array}{c}0.955 \\
(0.243-3.756)\end{array}$ & \\
\hline \multicolumn{7}{|l|}{ Exercise } \\
\hline Not a routine & 59 & 32.8 & 121 & 67.2 & 1.950 & 0.235 \\
\hline
\end{tabular}




\begin{tabular}{|c|c|c|c|c|c|c|}
\hline \multirow{3}{*}{ Variable } & \multicolumn{4}{|c|}{ Hypertension Status } & \multirow{3}{*}{ OR } & \multirow{3}{*}{ Sig } \\
\hline & \multicolumn{2}{|c|}{ Hypertension } & \multicolumn{2}{|c|}{ Normal } & & \\
\hline & $\mathrm{n}$ & $\%$ & $\mathrm{n}$ & $\%$ & & \\
\hline (<3 times/week) & & & & & $(0.756-5.092)$ & \\
\hline Routine & 6 & 20 & 24 & 80 & & \\
\hline \multicolumn{7}{|l|}{ (> 3 times/week) } \\
\hline \multicolumn{7}{|l|}{ Job status } \\
\hline \multirow[t]{2}{*}{ Low } & 42 & 30.4 & 96 & 69.6 & 1.458 & 0.728 \\
\hline & & & & & $(0.382-5.570)$ & \\
\hline \multirow[t]{2}{*}{ Moderate } & 20 & 33.9 & 39 & 66.1 & 1.709 & \\
\hline & & & & & $(0,422-6,920)$ & \\
\hline High & 3 & 23.1 & 10 & 76.9 & & \\
\hline \multicolumn{7}{|l|}{ Vegetable Consumption } \\
\hline Low & 59 & 33 & 120 & 67 & 2.049 & 0.193 \\
\hline (<3 Portion) & & & & & $(0.797-5.265)$ & \\
\hline Enough & 6 & 19.4 & 25 & 80.6 & & \\
\hline \multicolumn{7}{|l|}{ (> 3 Portion) } \\
\hline \multicolumn{7}{|l|}{ Age } \\
\hline At Risk & 43 & 43.9 & 55 & 56.1 & 3.198 & $<0.000$ \\
\hline ( $\geq 45$ Years Old) & & & & & $(1.732-5.907)$ & \\
\hline Not At Risk & 22 & 19.6 & 90 & 80.4 & & \\
\hline$(<45$ Years Old $)$ & & & & & & \\
\hline
\end{tabular}

The results of the multivariate analysis that was carried out using binary logistic regression showed that the nutritional status variable of obesity was the dominant variable after age for the occurrence of hypertension in the coastal area of Medan Belawan. Obesity nutritional status has a large risk 2.284 times biggger risk of suffering from hypertension than non-obese nutritional status $(\mathrm{p}=0.028)$. This is in line with the research of Darmawan (2018), Adam (2019), and Suranti (2019), namely that there was a relationship between nutritional status of obesity and the incidence of hypertension with a consecutive $p$ value, namely $\mathrm{p}=0.001 ; \mathrm{p}=0.007$; and $\mathrm{p}=0.001$.

Table 4. Final Model of Risk Factors for Hypertension

\begin{tabular}{lccccc}
\hline \multicolumn{1}{c}{ Variable } & $\mathrm{B}$ & $\mathrm{S}, \mathrm{E}$ & $\mathrm{P}$ & $\mathrm{OR}$ & $95 \% \mathrm{CI}$ \\
\hline Age & 1.112 & 0.344 & 0.001 & 3.040 & $1.549-5.966$ \\
Obesity Nutritional Status & 0.826 & 0.377 & 0.028 & 2.284 & $1.091-4.780$ \\
Constant & 18.547 & 40193.582 & 1.000 & 113504919.176 & \\
\hline
\end{tabular}

Information: $\mathrm{R} 2=25.8 \%$

Based on the research of Jean (2017) with a systematic review method, it is found that the nutritional status of obesity is associated with an increase in blood pressure. In the condition of obesity nutritional status, the occurrence of insulin resistance and impaired endothelial function of blood vessels, causing vasoconstriction and sodium reabsorption in the kidneys and causing an increase in blood pressure (Angesti, Triyanti, n.d.). An increase in BMI associated with an increase in norefinephrine in the kidneys suggests a relationship between sympathetic nervous system activation with obesity and renin release. The activation of the sympathetic nervous system causes an increase in blood pressure by increasing the activity of the renin angiotensin aldosterone system (RAA) (Brady, 2017). 
Table 5. Probability Value of Hypertension Based on Risk Factors for Age and Nutritional Status of Obesity

\begin{tabular}{|c|c|c|c|}
\hline Age At Risk & Obesity Nutritional Status & Probability Formula & $\begin{array}{c}\text { Probability Value } \\
(\%)\end{array}$ \\
\hline Yes & Yes & $\begin{aligned} P(x) & =1 /\left(1+2.718^{-20,485}\right) \\
& =0.9999999987\end{aligned}$ & 99.99999987 \\
\hline Yes & No & $\begin{aligned} P(x) & =1 /\left(1+2.718^{-19,659}\right) \\
& =0.9999999971\end{aligned}$ & 99.999999971 \\
\hline No & Yes & $\begin{aligned} P(x) & =1 /\left(1+2.718^{-19,373}\right) \\
& =0.9999999961\end{aligned}$ & 99.99999961 \\
\hline Yes & Yes & $\begin{aligned} P(x) & =1 /\left(1+2.718^{-18,547}\right) \\
& =0.9999999912\end{aligned}$ & 99.99999912 \\
\hline
\end{tabular}

To control hypertension in patients who are $\geq 45$ years old and have a nutritional status of obesity, it is necessary to hold exercise and promote the selection of appropriate food for people aged $\geq 45$ years regularly once a week in coastal areas so that the nutritional status remains within normal limits. If within 4 to 6 months of implementing a healthy lifestyle you cannot lower the expected blood pressure (Indonesian Association of Cardiovascular Specialists, 2015).

\section{Conclusion and Suggestion}

The hypertension status in the coastal area of Medan Belawan is still high with a percentage of $31 \% \quad(95 \%$ CI $=23.5 \%$ $-38.3 \%)$. Their average blood pressure is in the pre-hypertensive category (systolic $=$ $133.32 \mathrm{mmHg}$, and diastolic $=80.55$ $\mathrm{mmHg}$ ) and their blood pressure is included in the category of hypertension level 2 (systolic $=133.32 \mathrm{mmHg}$, and diastolic $=80.55 \mathrm{mmHg}$ ). Hypertension sufferers have a high level of salt consumption, the majority have obesity nutritional status, do not have routine exercise habits, low work status, low vegetable consumption. The final model of probability binary logistic regression based on the risk factors for hypertension in the coastal population of Medan Belawan, namely ()$=1 /(1+\mathrm{e}-\mathrm{y})$ with a value of $y=18,547+(1,112)$ (Age) $+(0.826)$ (Obesity nutritional status). If a person is $\geq 45$ years old and has a nutritional status of obesity, the probability of developing hypertension is $99.99 \%$. Suggestions that can be given to the Health Office are the need to hold exercise and promote the selection of appropriate food for people aged $\geq 45$ years regularly once a week in coastal areas so that their nutritional status remains within normal limits. In further research, the research questionnaire needs to be sharpened because the research variables under researched tend to be homogeneous.

\section{Acknowledgments}

We would like to thank you for Dean Public Health Faculty of Universitas Islam Negeri Sumatera Utara Medan who support us. We would like to thank you for Ryan Rahmat Tanjung and Waridah Santi Siregar who helped us by data collecting and analysis.

\section{References}

Adam, L. (2019). Determinants Of Hypertension In Elderly. Jambura Health and Sport Journal, 1(2).

Angesti, Triyanti, S. R. (n.d.). History of Family Hypertension as a Dominant Factor of Hypertension in Class XI Adolescents at SMA Sejahtera 1 Depok in 2017. 46(1).

Begossi, B. O. (2013). Blood Pressure and Hypertension among Coastal Fishermen in South-east Brazil. Journal of Community Medicine $\mathcal{E}$ Health Education, 04(01), 1 - 5. https://doi.org/10.4172/2161-0711. 1000261

Brady. (2017). Obesity Related Hypertension in Children. Front Pediatr.

Chen, X., Wei, W., Zou, S., Wu, X., Zhou, B., Fu, L., ... Shi, J. (2014). Trends in the prevalence of hypertension in island and coastal areas of China: A systematic review with meta-analysis. American Journal of Hypertension, 27(12), 1503 - 1510. 
https://doi.org/10.1093/ajh/hpu02 6

Darmawan, Hasbullah, Abdullah Tamrin, N. (2018). Sodium Intake and Nutritional Status Against Hypertension Levels in Outpatients at Makassar City Hospital. 25.

Elperin, D. T., Pelter, M. A., Deamer, R. L., \& Burchette, R. J. (2014). A Large Cohort Study Evaluating Risk Factors Associated With Uncontrolled Hypertension. Journal of Clinical Hypertension, 16(2), 149 154.

https://doi.org/10.1111/jch.12259

Indonesian Association of Cardiovascular Specialists. (2015). Guidelines for the Management of Hypertension in Cardiovascular Disease.

Indonesian Health Ministry. (2007). Basic Health Research Report. Jakarta: Health Research and Development Agency.

Indonesian Health Ministry. (2013). Basic Health Research Report. Jakarta: Health Research and Development Agency.

Indonesian Health Ministry. (2018). Basic Health Research Report. Jakarta: Health Research and Development Agency.

Ingrid, S. K. Krishnadath1, Vincent W. V. Jaddoe, L. M. N. V. and J. R. T. (2016). Ethnic differences in prevalence and risk factors for hypertension in the Suriname Health Study: a cross sectional population study.

Julkrismi, E. (2018). The Influence of Coastal Community Life Patterns on Settlement Patterns at Pasar Bawah Beach. Aisyiyah University.

Kozier. (2010). Clinical Nursing Practice Textbook (5th ed.). Jakarta: EGC.

Muthukrishnan, G., Pillai Uma, S. B. K., \&
V., A. V. (2018). A cross sectional study of hypertension and their risk factors in fishermen of Chennai district. International Journal of Community Medicine And Public Health, 5(6), 2464. https:// doi.org/10.18203/2394-6040. ijcmph20182178

Noubiap, J. J., Essouma, M., Bigna, J. J., Jingi, A. M., Aminde, L. N., \& Nansseu, J. R. (2017). Prevalence of elevated blood pressure in children and adolescents in Africa: a systematic review and meta-analysis. The Lancet Public Health, 2(8), e375e386.

https:// doi.org/10.1016/S2468-2667 (17)30123-8

Rahajeng, Ekowati, Dewi Kristanti, dan N. K. (2016). Differences in the rate of occurrence of hypertension according to sodium consumption [Prospective Cohort Study in Bogor City, West Java, Indonesia.

Rusliafa, J., Amiruddin, R., \& Noor, N. (2014). Komparatif Kejadian Hipertensi pada Wilayah Pesisir Pantai dan Pegunungan di Kota Kendari. Mkmi, 1, 1-13. Retrieved from

http:/ / pasca.unhas.ac.id/jurnal/file s/d94f67a89af9dcb98fda87051cb39c6 a.pdf.

Yodang, Y., \& Nuridah, N. (2019). Prevalence and Determinants of Hypertension in Coastal and Estuarine Communities. International Journal Medical Reviews, 6(4), 128-134. https://doi.org/10.30491/IJMR.2019. 100909.Copyright 